\title{
Labour and consumption. A new opportunity for capitalism resulting from the COVID-19 pandemic
}

\author{
Trabajo y consumo. Una nueva oportunidad para el capitalismo resultante de la pandemia COVID-19
}

Marco Ambrosi De la Cadena

Università Vita-Salute San Raffaele, Italy

Milano, Italy

m.ambrosi1@studenti.unisr.it

\section{ABSTRACT}

The article presents a philosophical discussion about how the economic restructuring after the COVID-19 recession is based on two main factors: labour precariousness and consumption stimulation. From a review of data and literature about global economic growth and incomes from big companies like Amazon, it is possible to suggest that capitalism is facing a decline yet not a structural crisis. Nonetheless, labour after the outbreak is damaged by the application of flexibilization and informality - particularly telecommuting and immaterial labour - as seen in countries like Ecuador, Italy, India, and United States. Also, companies and governments are calling for a boost of consumption to save the economy based on fiscal policies, consumerism, and a 'cleaning' of consumption. In conclusion, a theoretical alternative is a microphysics of struggle understood as a politicization of the private space and a re-definition of labour as a material activity that requires better conditions for workers.

Keywords: COVID-19; labour; consumption; telecommuting; working from home; economic recovery

\section{RESUMEN}

El artículo presenta una discusión filosófica sobre cómo la restructuración económica, posterior a la recesión por el COVID-19, se basa en dos aspectos principales: precarización del trabajo y la estimulación del consumo. A partir de una revisión de data y literatura sobre el crecimiento económico global y sobre los ingresos de grandes compañías como Amazon, es posible sugerir que el capitalismo está enfrentando una caída más no una crisis estructural. Sin embargo, el trabajo después del rebrote masivo se ha visto afectado por la aplicación de la flexibilización y la informalidad particularmente del teletrabajo y el trabajo inmaterial - como se ha visto en países como Ecuador, Italia, India y Estados Unidos. Así mismo, compañías y gobiernos recurren a incentivar el consumo para salvar la economía basados en políticas fiscales, consumismo y una 'limpieza' del consumo. En conclusión, una alternativa teórica es una microfísica de la resistencia, entendida como la politización del espacio privado y como una redefinición del trabajo como una actividad material que requiere mejores condiciones para sus trabajadores.

Palabras clave: COVID-19; trabajo; consumo; teletrabajo; recuperación económica 


\section{INTRODUCTION}

The COVID-19 outbreak has shown once again the fragility of capitalist economy and the vulnerability of humankind. However, the post-lockdown stage will be an invaluable opportunity for capitalism to reinvent itself, as happened after the great depression and the 2008 crisis. This is because flexibility is a central feature of capitalism as long as it serves its purpose: accumulation of capital regardless of any consequences or decisions to be made. The pandemic outcome is widely discussed within academic circles in terms of health, medicine, biosecurity, and economics. Yet an aspect that is not being analysed enough within scholarship are the social effects for labour and consumption.

The main objective of the article is to present a political-philosophical discussion about flexibilization of labour and boost of markets, as strategies for economic recovery. The argument is that the post-COVID-19 scenario is weakening labour rights and conditions through legal reforms and telecommuting. Likewise, consumption is presented by companies and governments, as a 'clean action' that contributes to the economy without any sanitary risk; however, their intention is to recall our consumerist subjectivity, which has been 'asleep' during the confinement, to vent tensions and frustrations derived from the pandemic, a so-called shopping revenge.

Measures to overcome the ongoing situation are different from region to region. Currently, countries around the world are facing many difficulties such as: economic contractions, employment loss, and consumptions declines. According to IMF projections (International Monetary Fund, 2020) closed in October, the global GDP growth will be -4.4 , for advanced economies $-5.8 \%$, and for emerging and developing economies $-3.3 \%$. Moreover, estimations from some countries are deeply pessimistic: Libya $-66.7 \%$, Peru $-13.9 \%$, Spain $-12.8 \%$, Argentina $-11.8 \%$, Ecuador $-11 \%$, Italy $-10.6 \%$, India $-10.3 \%$, France $-9.8 \%$, United Kingdom -9.8\%, Mexico -9\%, Canada $-7.1 \%$, Germany - $6 \%$, Brazil $-5.8 \%$, and United States $-4.3 \%$.

These numbers could have several explanations. Some are discussing about a "coronavirus crisis" (Karabag, 2020; Leiva-Leon et al., 2020; Lucchese \& Pianta, 2020) after economic contractions and drawdowns in financial markets - especially commodities and stock shares - during the first weeks following the outbreak. Nevertheless, there is no such economic crisis in structural terms, in the worst case-scenario countries are suffering a strong recession with unequal effects for the most. For instance, some nations are displaying a positive growth for 2020 (International Monetary Fund, 2020): Guyana 26\%, Bangladesh $3.8 \%$, Benin $2 \%$, China $1.9 \%$, Ethiopia 1.9\%, Tanzania 1.9\%, Côte d'Ivoire $1.8 \%$, Turkmenistan $1.8 \%$, Vietnam $1.6 \%$, and Guinea $1.4 \%$, figures that are later discussed.

\section{METHODS}

The article aims to discuss, from a philosophical approach, conditions for labour and consumption after the COVID-19 outbreak. For that end, a bibliographical research about economic projections, employment information, law reforms, and consumption levels was developed. A general overview of global economy allows to assert that the world is not facing a structural crisis but a strong recession as is observed from IMF projections and information from big companies. Academic studies, surveys and media publications referred to working circumstances and market expectations were also revised in order to obtain data about the current situation. Specific cases such as Amazon incomes and legal reforms in Ecuador were considered for highlighting the COVID consequences for 'real economy' and formal employment within an official neoliberal speech.

Based on a critical analysis of data and literature, a philosophical discussion about telecommuting is stated, taking 'informality' and 'flexibilization' as core concepts. The debate emphasizes two issues: vulnerability of employees during economic recovery and, how the dematerialisation of labour hinders any opportunity for social struggling.

Later, media publications and surveys related to consumer behaviour, expectations, and expenditure during the lockdown are reviewed; particularly, consumption in China is considered as an example of recovery. Further, a theoretical debate about consumption is outlined on three points: fiscal policy, consumerist 
subjectivity, and 'cleaning' of consumption. The main idea supported is the one about "shopping revenge", i.e., consumerism as a relief for the quarantine and its lockdown. Finally, some cases of changes in business turns within big companies are exposed for arguing about flexibility in global offer and demand after the COVID-19 outbreak.

\section{RESULTS}

\subsection{A political-philosophical analysis of the post-COVID-19}

The post-COVID-19 is bringing about significant changes at all levels of world society, one of which will undoubtedly be related to economic aspects. Thus, from capitalism will be the time for designing plans and movements that change trade relations, consumption patterns, and labour conditions, in other words, a reinvention for capitalism as an economic system. As aforementioned, capitalism is not suffering a structural crisis but a recession that will affect the most to the poorer. Historical data shows that bear markets do not always coincide with recessions, because there is no such a marked line between financial markets sell-offs and real economy in times of uncertainty (Carlsson-Szlezak et al., 2020). The 2020 scenario shows that a fall down in commodity prices does not imply an economic recession nor does an output loss means automatically a consumption decay. This is a consequence of capitalism flexibility that permanently adapts itself to the surrounding conditions in order to accumulate; some could lose money and assets but the system itself never gives up.

Inequity and contradiction, essential to capitalist economy, take shape at the impact level of the pandemic: the poorer are more affected than the wealthier who have accumulated capital and social facilities throughout time. Similarly, small and medium enterprises (SME) are facing harsher problems than big enterprises whose market coverage is continuously expanding regardless of lockdown, restrictions, and shortage. Then, the pos-COVID-19 does not constitute a new scenario, but it confirms the structural asymmetries of capitalism. Take as an example e-commerce presented as an architype of 'free and fair competition' between all kinds of providers: so far big enterprises have benefited from the exponential increase of demand through APPs and electronic platforms, while local entrepreneurs struggle with logistical complications and additional costs for services. As Bartik et al. (2020) describe $41,4 \%$ from more than 5,800 small businesses surveyed along United States were temporarily closed due to COVID-19 situation.

An opposite case is Amazon whose revenues for 2020 first quarter (Q1) grew almost $\$ 16$ billion dollar from the year-ago period and for the Q2 were expecting an extra $\$ 4$ billion in operating profits, although each AMZN share lost more than 2 dollars during Q1 (Swartz, 2020). This shows that 'real economy' is not entirely connected to financial markets and speculation, i.e., while stock markets collapse consumers are still buying (big groups are still profiting) despite uncertainty and economic recession.

Capitalism is not facing a crisis, but people are. The pandemic consequences are dramatic for the most, until mid-May 2020 unemployment reached 36 million in United States, 3.5 million in Spain, a projection to 3.4 million in United Kingdom by the end of June, 500,000 job losses in Italy, 122 million job losses in India, 150,000 in Ecuador just in April, and in Africa around half of jobs were at risk (Hutt, 2020). On the other hand, the 'coronavirus crisis' has also allowed an opportunity to increase income and market coverage: in US business related to online grocers, gaming, food delivery, video streaming, meal kits, alcohol, home improvement, warehouse clubs, supermarkets and general merchandise sold through e-commerce have improved their sales (Leatherby \& Gelles, 2020). Only grocery sales in the US from $11^{\text {th }}$ to $18^{\text {th }}$ March were up $79 \%$ from the previous year, showing that this time has not been a complete failure for some.

\subsection{Precariousness of labour: informality, flexibility, and telecommuting}

'Surprisingly' countries from Asia and Africa, as aforementioned, present a GDP growth projection for 2020; a possible explanation could arise from labour market conditions since most of them are primary economies with precarious legislation or well-known maquilas, i.e., districts with low wages and flexible work legislations. Whereas, developed countries will try to reduce the economic decline through precariousness of labour. 
Following the pandemic, demand for biosecurity supplies and health goods have increased and precisely most of their producers are located in maquila regions. Therefore, economic growth based on cheap workforce is deepened after the first COVID outbreak once market labour is more vulnerable to informality and unemployment in peripheral countries. In the Asia-Pacific region for example nearly $60 \%$ of nonfarm workers are informal without social protection and variable daily incomes (Dabla-Norris \& Rhee, 2020). So, it is not a coincidence that countries from this region - like Myanmar with over $80 \%$ of informal workers - are those reporting a positive projection for GDP.

Informality and flexibility are not new phenomena, e.g., in Latin America they 'boomed' from the 70 as a result of economy modernisation and neoliberal adjustment measures. Discourses and policies about flexibilization - understood as relaxing labour legislation - recurrently appear in the region during crisis times bringing often a growth in informal working. A noteworthy case is Ecuador that during the 9os faced a deep economic crisis after the approval of the "law for the economic transformation of Ecuador" that allowed privatisation of national resources, bank bailout, and labour flexibilization. As result, the underemployment ${ }^{2}$ rate rose from $42 \%$ in 1998 to $59 \%$ in 1999 and $61 \%$ in 2000 (Observatorio de la PyME, 2010), later in 2001 it fell to $56 \%$ and to $54 \%$ in 2004 however the new jobs were under precarious and unstable conditions.

Lately, the Parliament of Ecuador approved "humanitarian law"3 (Asamblea Nacional del Ecuador, 2020) which contains a cluster of alleged 'state aids' for education, social security, renting, productive financing, and labour. The reform introduces in the Labour Code the figure of "mutual agreement" that allows a considerable modification of contractual conditions after a 'consensus' between workers and employers. Moreover, legal figures such as "emergency special contract", "emergency reduction of workday" and "vacation use" were imposed for legalising the infringement of workers' rights. Before the COVID-19 outbreak Ecuador already had a complicated labour outlook, in December 2019 the $46.7 \%$ of employment was informal and just $38.8 \%$ of working population was fully employed (Instituto Nacional de Estadísticas y Censos, 2019). Nowadays, after the pandemic only in April 2020 150,000 jobs were lost and by the end of the lockdown more than 500,000 unemployment applications were expected.

Under a flexible legal framework, a consensual agreement between employers and employees is unattainable, the worker is always at a disadvantage and in need. For that reason, workers are pushed towards informality in order to survive. But what is informal work and how is connected to economic recovery?

Informality is widely discussed from many perspectives and conceptions. Supriya Routh (2011) summarizes the three main conceptual frameworks to explain the so-called informal employment. 1) The 'dualist theory' based on apparent dichotomies rural/urban, agriculture/industry, and non-capitalist/capitalist, expresses that formal and informal sectors are simultaneously developed but unrelated one to the other. 2) The 'structuralist theory' argues that formal and informal are inherently linked to each other, but the latter is just part of the modern production process. 3) The 'legalist thesis' (contained by the structuralist theory) affirms that the costly, cumbersome, and time consuming legal and tax obligations required by the formal economy 'compel' individuals to operate informally. Nevertheless, in response to each conceptualisation is possible to emphasise that the 'dualist theory' is naive when ignores the deep-rooted relations between formal and informal sectors. The structuralist approach highlights the systematic connection among formal/informal but overlooks that informality assures and strengthens formality by means of impoverishment. The legalist standpoint justifies informality through the 'choice argument': it is true that evading legal duties is a decision for big companies but for the most is a matter of survival.

From an intersectional perspective informality is not just an economic situation - even in labour terms it implies cultural, social, ethnic, identity and gender conditions. In the COVID context informal working will play a crucial role during the 'economic recovery'; for instance, labour flexibility and informality ease

\footnotetext{
$1 \quad$ Also called "Ley Trolebus"

2 The ambiguous concept of underemployment in Ecuador includes informal workers and people with jobs whose wage does not cover the minimum salary nor the entire workday.

3 The official name is "Ley Orgánica de apoyo humanitario para combatir la crisis sanitaria derivada del COVID-19"
} 
adjustments of working costs in periods of crisis and economic contractions (Sandoval Betancour, 2014). In the case of Ecuador or Asian countries informality and flexibility are intensely related since the latter pushes workers towards the former through reduced workdays, precarious wages, unfair contracts and instability. In crisis periods governments and companies resort to flexible-labour reform because it makes formal what previously was considered informal or even illegal.

Thus, big capitals maximise profits offering cheap goods as a result of almost disappearing the economic value of workforce, i.e., reducing wages, increasing workdays, and eliminating social benefits. In general, flexibility and informality denaturalise the concept of labour. According to Marx a worker is constrained to sale her workforce in exchange of a salary, so labour process is understood as workforce consumption by the capitalist who controls and owns the worker' labour and its product. Following the neoliberal reform, capitalist control and worker dependence are greater because informality places the worker in a condition of survival once her work partially meets her minimum needs. She is forced to 'devaluate' her workforce and/or to increase her workday with several jobs for earning the minimum wage.

Today a worker sells her workforce as Marx says but also her survival in exchange of an insufficient wage, in this sense her reality differs from the classic proletarian. She is not subjected anymore to any salary nor legal form established in the already precarious work law. Flexibility and informality attempt to vanish any link between employers and employees, for that reason, a full contract of employment becomes a privilege for some against a liberalised labour exploitation for the most. Free of legal and political restrictions capitalists tend to take advantage of the 'excessive' work supply formed by unemployed and underemployed people. Indeed, as a consequence of lack of employment workers are pushed to accept unhuman labour conditions and lower wages than those legally stipulated. Furthermore, informal and flexible labour entails the renounce of unionisation and defence of labour rights; then, it is illusory to talk about agreements between employees and employers as the reform suggests in Ecuador.

The problem is not just an income issue ${ }^{4}$, because exploitation and rights infringement are involved. Women, migrants, peasants, and indigenous are mostly exposed to those labour conditions which reaffirm and deepen social and gender hierarchies. As Recio (1998) points out when women got into the labour market they occupied flexible jobs mainly part-time that allow them to match both productive and reproductive work. Therefore, formal economy requires informal economy to develop non-intensive capital and low productivity activities. Capitalism needs informality to relegate the most to poverty assuring minimum conditions for reproductive labour and care economy. The situation is evidenced during the pandemic outbreak when customary discriminations are evident in the workforce for healthcare and services that is highly gendered, racialised, and ethnicised in most parts of the world (Harvey, 2020). The virus does not take into account gender, class, and race but flexibility does. The forefront working class bears the brunt of either being at risk from contracting the virus or of being laid off with no resources because of the economic retrenchment enforced by the virus.

Philosophically speaking informality has no form, this means from the worker's perspective that she is not in nor out the system. She does not belong to the formal structure with rights and benefits, but neither is completely out of the economic circle where her workforce is essential. The informal worker is trapped in a limbo a 'no one's land' where everything is allowed in name of production, profitability, and survival. The limbo is also existential when in order to survive a worker is condemned to accept any illegal or arbitrary condition, the capitalist knows that and takes advantage of it. In Marxist terms informality resembles the expansion of formal subsumption to real subsumption of the labour process which actually is really subsumed to the speculative conditions of neoliberalism. After all, it is not a coincidence that informality is associated to insecurity, peripheral suburbs, insalubrity, lack of services (water, electricity, and sewerage), pollution, mortality, etc., all of them are social, legal, urban, economic and environmental issues always towards the poorest.

$4 \quad$ In several cases an informal worker could even earn a fixed monthly payment 


\subsubsection{A philosophical discussion on telecommuting}

Besides, flexibility is also taking form as 'smart working', 'e-working', 'telecommuting' 'teleworking' or 'working from home' (WFH). These are defined as "the activity of working at home, while communicating with your office by phone or email, or using the internet" (Cambridge Dictionary, 2020). Prima facie sounds marvellous to work from home however it is not available for everyone and involves in most cases a dramatic change in labour conditions. For example, in Italy smart working is a privilege since only $30 \%$ of all the occupations can be performed from home, the remaining $70 \%$ are elementary activities including operators, artisans, sales and service workers; then, this occupational inequality is translated into inequalities in wage distribution, internet access and exposure to the pandemic risks (Cetrulo et al., 2020). Those more benefited from WFH appear to be male, older, graduated, married, living in northern regions, full-time worker or public servant (Bonacini et al., 2020). Similar evidence was found in the USA where WFH employees are more likely to be white, have a college degree, be born in USA, have a better income distribution (Mongey \& Weinberg, 2020).

For the privileged smart workers, taking the office at home leads to transforming the private (intimate) space into a place of labour exploitation; there is no division between intimacy and productivity once the line that separates resting than working is blurred, even bed turns into an office lot. For some it could be radical to affirm that teleworking resembles slavery but considering workday and control both are endless and timeless on the worker's shoulders. Clock is significant in the traditional-labour-place, marks the beginning and the end of working time, i.e., when 'freedom' from the capitalist starts and finishes. Currently, the watch is irrelevant because the teleworker's duties are present all the time inside her head, goals and objectives are met 'whenever' she wants including weekends and late nights. Thus, the working week has no ending, and the worker has no resting everything without much effort from the capitalist.

Telecommuting represents another triumph of technic over work and humankind: it dispenses with workspace understood as the place where surplus is produced. Historically speaking, factories or offices have been seen as territories of exploitation but once labour is dislocated through technology it becomes a simple activity in which exploitation almost disappears. It is no longer a factory the space to dehumanise workers with machines and computers, instead, dehumanisation takes place at their residency that is not anymore, a spot for enjoying, family sharing, and 'reloading workforce'. Factory as building allowed workers to identify their exploiter and exploitation; the 'sacrifice of working' was materialised in a place to which they could claim for their rights with strikes or stoppages. Nowadays, for a 'smart worker' nothing of that is possible at her house where she barely could distinguish working from resting when her exploiter's orders electronically arrive at any time.

Home has never been a safe place for women and children rather it has been the place to exercise oppression against them through gender violence, care work, and isolation. Nonetheless, the teleworker's house is where gender violence, labour exploitation, inequality, and mental health issues are 'tenderly' deepened. Several surveys, studies, publications (Andrew et al., 2020; Espinoza, 2020; Sevilla \& Smith, 2020; Williams, 2020) around the world discuss how during the pandemic women, despite generalised teleworking for everybody, 'bear the brunt' of childcare, housework, and affective labour. Thus, smart working is a sharp move for capitalism: expanding simultaneously the gender gap at home and at labour in order to guarantee reproductive work and workforce care.

As a consequence of lockdown and social distancing home has been turned into an isolated spot in which each person by herself has to deal with the virus, gender violence, and all social needs. Hence society and State have nothing to do inside the house where everyone by her own has to satisfy her needing including education and health. Social institutions cease to operate within those walls, any inconvenience - even at teleworking - has to be solved by expenses of the individual. A simple case, if a student has no computer nor broadband internet the State is no compelled to provide them but herself as individuals.The private space which is political as feminism asserts is deprived (privatised) of any social facility given the priorities

\footnotetext{
5 Consider also the case of the COVID positive people who have to take care of themselves at home since the sanitary
} system was collapsed, it was a hand wash for States. 
linked to the outbreak and later recovery. Coronavirus is the perfect excuse to free either the State of its obligations or the capitalist of any labour restriction.

Telecommuting as well is a form of flexible labour because workers' rights are lessened: healthcare, work clothing, workday, unionisation, work feeding, overtime, labour safety, or holidays are partially or completely uncovered by the 'tele-employer'. In developing countries like India where $70 \%$ of employment is informal, smart working is a relevant modality for self-employed activities representing a $29 \%$ as compared to wage and salaried employees with $21 \%$ (Bhatt et al., 2020). WFH is linked to managerial undertakings and specially to the so-called 'immaterial labour', an activity that produces through technology and telecommunications immaterial goods such as services, cultural products, knowledge, or networks (Hardt \& Negri, 2001) ${ }^{6}$.

Philosophically speaking, within immaterial labour the worker is "increasingly further removed from her object of labour", she does not figure it out how, when and where that object is produced. WFH is mostly immaterial labour and also implies a process of labour dematerialisation in which exploitation is almost imperceptible. Objective conditions of labour (means of production, relations of production, and goods) have been 'informationalised' rendering the production process as a cluster of bits and data. It softens exploitation that becomes comfortable, home-like, and desirable for most workers who are dreaming about leaving a cold and lonely office, unknowing that in exchange their labour rights are diminished.

This 'teleprocess' of production is highly profitable besides it is simplified in terms of physical infrastructure, maintenance, personnel, management, taxation, and general costs of production. It is exceedingly lucrative based on a great contradiction: highly qualified and low-earning workforce produces sophisticated goods or services with a great market value. Smart working is mainly applied to 'subtle' jobs within a technological division of labour such as: office work, services, hi-tech, entertainment, software design, and even 'telemedicine' all of them linked to extreme profitable industries during and after the lockdown. Moreover, immaterial labour is closely related to affective labour highly demanded by a confined and sick society. Women who are most in charge of these activities have been vastly exploited by an assigned caring role both in public and private spheres.

Thinkers such as Žižek (2020), Hardt, and Negri are respectively optimistic about the pandemic and immaterial labour in the sense that a new kind of communism could emerge. Yet immaterial and flexible labour based on coronavirus as an excuse, are isolating workers, exacerbating oppression and precariousness for the most. An organised social movement - including women, workers, students, peasants, diversities - is more difficult to achieve in a context of informality and unevenness. For the next years people will be facing harsher conditions to satisfy the most basic needs, a struggling scenario seems to be further away than before. The pandemic makes social organisation challenging for sanitary reasons, although the most influential aspect is the setting of individuality as a survival strategy.

On the other hand, Chul-han (2020) says that the virus will not defeat capitalism because is unable to make the revolution, it just isolates and individualizes disabling any collective feeling. So, a theoretical alternative - instead of talking about international transformations and big movements - is the construction of a microphysics of struggle within the working context. As labour dematerialisation allows profits increase removing legal restrictions and cheapening production costs, the reply might be to 're-localise' working activities. That means making visible the placement and materiality of labour, profits, and goods produced for the market. The worker centrality within the production process must be recovered, since goods whether digital of physical are not made by technology but for workers and their capacities.

Flexibility and informality try to remove any link between worker and capitalist, in that sense, the concrete response is to politicise private and labour spaces. A call to organise workers towards all-time vindications such as full-contracts, higher wages, well-defined workdays, unionisation, pension plans, health insurance and all material conditions that improve life quality.

$6 \quad$ They establish three types of immaterial labour: a) industrial production that has been informationalised and has incorporated communication technologies in a way that transforms the production process itself, b) labour of analytical and symbolic tasks, which itself breaks down into creative and intelligent manipulation on the one hand and routine symbolic tasks on the other, c) an immaterial labour that involves the production and manipulation of affect and requires (virtual or actual) human contact, labour in the bodily mode. 


\subsection{Unstoppable consumption, an economic boost}

Another aspect recalled for economic recovery is stimulation of consumption understood by governments and international institutions as a global engine. Despite the outbreak and the following labour crisis people are still buying and spending. Solidarity as Žižek hopes is not the lockdown outcome, instead people are desperately attempting to get back jobs and consumption capacity at best. Ironically, in China International Women's Day was a large marketing event towards sales recovery for major brands (Estée Lauder, Lancôme or Nike) that experienced a double-digit sales growth comparing to last year (Zhang, 2020). Confinement or social distancing are not a limitation to market consumption, customers surveyed during the quarantine in China, United States, Brazil, India, Korea and Japan expressed their intention to increase online shopping for groceries, food takeout, delivery, household supplies, personal care, nonfood child products, and books/magazines/newspapers (Charm, Grimmelt, Jain, et al., 2020). Curiously, after the restrictions in China gasoline, wellness, and pet-care services bounced back (Jones, 2020).

Several surveys were been applied to find out consumers' behaviours and expectations in order to plan market strategies. Two aspects measured were optimism for economic recovery and change in overall spending (Charm, Grimmelt, Kim, et al., 2020), costumers from countries like Indonesia, China and India were highly optimistic and planning to increase spending. Inversely, Korea, Spain, France, Japan, Italy, Canada, UK, Argentina and United States were less optimistic and expecting a spending reduction. This ever-changing data is essential for defining advertisement, investment and consumption all over the world in post-lockdown times. Despite the optimism people are spending less because of jobs losses, new outbreaks, and lack of money. For that reason, the priority has been settled for markets and governments but how can consumption be boosted?

The 'creative' strategy to increase consumption in the middle of a crisis contains three elements: fiscal policy, consumerist subjectivity, and 'cleaning' of consumption. First, the IMF suggests as fiscal policy time-bound value-added-tax reductions or consumption vouchers for motivating people's expenditure (Gaspar et al., 2020). World leading institutions prefer to invest public funds for improving private profits rather than strengthening social services and facilities during the worst sanitary crisis in a century. They campaign for a profit-based policy pretending that big companies are the losers of the pandemic. Thus, policymakers could justify a new public salvage allowing tax cuts, public aids, and bankruptcy as a mechanism for receiving public funds, evading taxes, and reducing labour rights. 'Surprisingly' big enterprises are those more benefited from flexible loans, low interest rates, tax exceptions, and technical advisory; while most of SME and entrepreneurs face the recession by their own or receiving high interest rates, endless bureaucratic paperwork, and limited access to banking.

Second, the pandemic has not stopped consumption only slowed it down, the answer seems to be in ourselves. A sanitary awareness about COVID-19 is not equivalent to a consumption reduction even less to a raising of social consciousness. Confinement - through precariousness and advertisement - has strengthen individuality and consumerist subjectivity that was not modified nor criticised, it was just waiting for the re-opening after a long closure. For that reason, big companies are expecting a "revenge spending" from shopping-starved consumers who will overcompensate economy buying more than usual (Zhang, 2020). The lockdown vendetta will be to take back the lost time at home in which we stopped being who we are, fierce consumers. As it happened in the aftermath of Cultural Revolution when there was a "shopping revenge" as a political action against the Chinese government ( $\mathrm{Li}, 2 \mathrm{2020})$. Therefore, an unbridled consumption could be a collective action to vent the frustration and depression derived from the pandemic.

The third element is to carry out a 'cleaning' of consumption, recalling to our internal and latent consumerism based on two additional factors. One, creating an atmosphere of bargains, a pseudo 'long deal-season' an endless 'black Friday' which produces a feeling of opportunity and assertiveness. The message is that you should buy as companies are in need and prices are falling; nothing as false as that, many brands have risen prices as consequence of logistical difficulties and high demand. Advertisement and official discourses are appealing to a consumerist social 'compassion' towards big businesses: you should buy now to save 
jobs (companies) as you save money. Ironically, companies are the main beneficiaries of public policy meanwhile people are struggling to make a living.

Two, projecting consumption as a neat activity: social distancing and hygiene measurements cannot be a trouble for buying. Stores must resemble cleanliness offering - regardless of economic and environmental expenses - biosecurity elements, gloves, face masks, gel, water, openness, and anything that is necessary to make shopping safe. A sign that says, 'Don't panic!' is displayed on a boutique's window in Milano, that means that the store is clean, and that shopping is a harmless relief from confinement. You can trust in your store which is cleaner and safer than a park or even your house. Thus, consumption is relocated in shimmering places, don't panic! Every purchase is guaranteed in sanitary terms as long as you use gloves and gel provided by the companies. Moreover, you can acquire sanitary implements, medicines, fashionable face masks and anything to prevent the virus, what matters at the end is that you spend.

Offer and demand are also flexible, understood as their capacity to adapt themselves to the existing conditions. During the outbreak industrial production has been adjusting itself to the global demand. Mass media are awarding several cases of successful changes in 'business turns' as a reply to shortage in health systems and markets. For example, Natura \& Co and LVMH both owners of cosmetics (Redacción El Financiero, 2020), the producer of liquor Pernod Ricard (Snouwaert, 2020), and AbInbev, the world's largest beer brewer (AblnBev, 2020) are companies that have been producing disinfectant alcohol, hand sanitizer, and antibacterial gel throughout the sanitary crisis. Instead of been a minute of philanthropy it reveals how adaptable capitalist production is in order to keep productivity, profitability, and branding. An insignificant investment is enough for industries to assure revenues modifying their unnecessary luxury goods for urgently needed supplies such as face masks, alcohol, health clothing, respirators, medicines, and even vaccines.

Before the pandemic capitalism was pretending to show a 'greener face' with recycled goods, lesser emissions, and 'circle economy'. Today, capitalism is flexibly configuring an 'antiseptic face' without germs, bacteria, and viruses; every commodity is produced following sanitary protocols reassuring that the virus is not produced/infected for shopping. However, this 'face wash' only tries to hide that in fact is consumerism which has provoked the pandemic. Capitalism is a system that never assumes its responsibilities, it is easier to impoverish the most, to deepen oppression and to accelerate consumption rather than proposing a transformation for global benefit.

\section{CONCLUSION}

In conclusion, it is possible to affirm that the solutions proposed for the COVID-19 economic impact are greater exploitation and maximisation of profits; the current situation is used as justification for the decrease of life quality and for the infringement of labour rights. In general terms, the pandemic has allowed the accumulation pattern of oligopolies associated to agribusiness, groceries, health, biosecurity, entertainment, social networks and logistics to deepen. While the affected industries are adapting their production to the new demands. Luxury consumerism, to say, will not disappear it has only been slightly modified to the conditions of social distancing and biosecurity requirements.

Capital is virus-immune and has no borders or social limits. During and after the outbreak, capital accumulation - including the primitive one - will see its real and formal subsumption sharpened through labour immateriality and dematerialization of production. This entails the impoverishment of the working class by means of informality and flexibilization in labour market, both oriented as strategies to maintain income margins. A political-philosophical alternative is to recover the definition of labour as a localised and material activity that produces surplus and goods for the market even if they are digital or electronic. This re-materialisation of labour requires a microphysics of struggle that organises workers towards concrete vindications such as full-contracts, higher wages, well-defined workdays, unionisation, pension plans, health insurance and all material conditions that improve life quality.

Finally, the consumerism boost based on an aggressive advertisement campaign with bargains and discounts, only tries to cover that the real problem is the current consumption pattern. The economic recession 
has not discouraged consumerism, yet it is assumed as a relief for social distancing and confinement. Companies and governments are taking advantage through fiscal policies of the consumerism subjectivity, for that reason, it is a priority that shopping resembles a clean activity without any risk. Someone could say that stimulating consumption in times of greater impoverishment is an unsustainable contradiction; that is to ignore that precisely capitalism rises on fatal contradictions though.

\section{REFERENCES}

AblnBev. (2020, March 22). AB InBev is manufacturing over 1 million bottles of hand sanitizer to donate to hospitals and frontline workers around the world. AblnBev. https://cutt.ly/fhIDhX7

Andrew, A., Cattam, S., Costa Dias, M., Farquharson, C., et al. (2020). How are mothers and fathers balancing work and family under lockdown? The Institute for Fiscal Studies. https://cutt.ly/5hIDx2U

Asamblea Nacional del Ecuador. (2020). Ley Orgánica de apoyo humanitario para combatir la crisis sanitaria derivada del COVID-19. https://cutt.ly/OhIDv3J

Bartik, A. W., Bertrand, M., Cullen, Z. B., Glaeser, E. L., et al. (2020). How are small businesses adjusting to Covid-19? Early evidence from a survey. National Bureau of Economic Research Working Paper Series. 26989. http://doi. org/10.3386/w26989

Bhatt, V., Grover, S., \& Sharma, A. (2020). COVID-19 pandemic, lockdown and the Indian labour market: Evidence from PLFS 2017-18. Indira Gandhi Institute of Development Research. https://cutt.ly/ThIDNPM

Bonacini, L., Gallo, G., \& Scicchitano, S. (2020). Working from home and income inequality: Risks of a "new normal" with COVID-19. Journal of Population Economy, 34, 303-36o. https://doi.org/10.1007/s00148-020-00800-7

Cambridge Dictionary. (2020). Teleworking. In Cambridge Dictionary. https://dictionary.cambridge.org/es/diccionario/ ingles/teleworking

Carlsson-Szlezak, P., Reeves, M., \& Swartz, P. (2020, March 3). What Coronavirus Could Mean for the Global Economy. Harvard Business Review. https://hbr.org/2020/03/what-coronavirus-could-mean-for-the-global-economy

Cetrulo, A., Guarascio, D., \& Virgilito, M. E. (2020). The privilege of working from home at the time of social distancing. InterEconomics, 3, 142-147. https://doi.org/10.1007/s10272-020-0891-3

Charm, T., Grimmelt, A., Jain, A., Kelsey, R., et al. (2020, July 8). Consumer sentiment is evolving as countries around the world begin to reopen. McKinsey \& Company. https://cutt.ly/8hlFaH3

Charm, T., Grimmelt, A., Kim, H., Mayank, Ortega, M., Staack, Y., \& Yamakawa, N. (2020, October 26). Consumer sentiment and behavior continue to reflect the uncertainty of the COVID-19 crisis. McKinsey \& Company. https:// cutt.ly/JhlFfvg

Chul-han, B. (2020, March 22). La emergencia ciral y el mundo de mañana. Diario El País. https://elpais.com/ ideas/2020-03-21/la-emergencia-viral-y-el-mundo-de-manana-byung-chul-han-el-filosofo-surcoreano-quepiensa-desde-berlin.html

Dabla-Norris, E., \& Rhee, C. (2020, April 30). A “New Deal” for Informal Workers in Asia. IMFBlog. https://blogs.imf. org/2020/04/30/a-new-deal-for-informal-workers-in-asia/

Espinoza, N. (2020, April 22). El rostro oculto de la cuarentea: Exceso de teletrabajo, desigualdad en las tareas domésticas y falta de comunicación. El Mostrador. https://cutt.ly/shIFhVV

Gaspar, V., Lam, W. R., \& Raissi, M. (2020, May 6). Fiscal Policies for the Recovery from COVID-19. IMFBlog. https:// blogs.imf.org/2020/05/06/fiscal-policies-for-the-recovery-from-covid-19/

Hardt, M., \& Negri, T. (2001). Empire (Fourth printing). Harvard University Press.

Harvey, D. (2020, March 20). Anti-Capitalist Politics in the time of COVID-19. Jacobin. https://jacobinmag.com/2020/03/ david-harvey-coronavirus-political-economy-disruptions

Hutt, R. (2020, May 14). The economic effects of COVID-19 around the world. World Economic Forum. https://cutt.ly/ nhIFxJb

Instituto Nacional de Estadísticas y Censos. (2019). Encuesta Nacional de Empleo, Desempleo y Subempleo (ENEMDU). https://cutt.ly/hhlFzds

International Monetary Fund. (2020). World Economic Outlook (October 2020). International Monetary Funda. https:// www.imf.org/external/datamapper/datasets/WEO

Jones, K. (2020, May 2). These charts show how COVID-19 has changed consumer spending around the world. World Economic Forum. https://cutt.ly/whlFc9k

Karabag, S. F. (2020). An Unprecedented Global Crisis! The Global, Regional, National, Political, Economic and Commercial Impact of the Coronavirus Pandemic. Journal of Applied Economics and Business Research, 10(1), 1-6. http://www.aebrjournal.org/uploads/6/6/2/2/6622240/joaebrmarch2020_1_6.pdf 
Leatherby, L., \& Gelles, D. (2020, April 11). How the Virus Transformed the Way Americans Spend Their Money’. New York Times. https://cutt.ly/ahIFbTx

Leiva-Leon, D., Pérez-Quirós, G., \& Rots, E. (2020). Real-time Weakness of the Global Economy: A First Assessment of the Coronavirus Crisis. Working Paper Series 2381, European Central Bank. https://ideas.repec.org/p/ecb/ ecbwps/20202381.html

Li, J. (2020, April 15). How coronavirus is changing what Chinese consumers buy. World Economic Forum. https://cutt.ly/ hhlGp3e

Lucchese, M., \& Pianta, M. (2020). The Coming Coronavirus Crisis: What Can We Learn? Inter Economics, 55(2), 98-104. https://doi.org/10.1007/s10272-020-0878-0

Mongey, S., \& Weinberg, A. (2020). Characteristics of Workers in Low Work-From-Home and High Personal-Proximity Occupations. White Paper. Becker Friedman Institute for Economics. https://bfi.uchicago.edu/wp-content/ uploads/BFI_White-Paper_Mongey_3.2020.pdf

Observatorio de la PyME. (2010). Analisis del mercado laboral ecuatoriano 1990-2009. Universidad Andina Simón Bolívar, Sede Ecuador. https://cutt.ly/WhIGxFj

Recio, A. (1998). La crisis del Trabajo. Mientras Tanto, 73, 21-41.

Redacción El Financiero. (2020, July 4). Natura usa sus fábricas para producir exclusivamente gel antibacterial y artículos de higiene. El Financiero. https://cutt.ly/yhIGmu7

Routh, S. (2011). Building Informal Workers Agenda: Imagining "Informal Employment" in Conceptual Resolution of “Informality.” Global Labour Journal, 2(3), 208-227. https://doi.org/10.15173/glj.v2i3.1106

Sandoval Betancour, G. (2014). La informalidad laboral: Causas generales. Equidad \& Desarrollo, 22, 9-45. https://doi. org/10.19052/ed.3247

Sevilla, A., \& Smith, S. (2020). Baby steps: The gender division of childcare during the COVID19 pandemic. Centre for Economic Policy Research. https://cepr.org/active/publications/discussion_papers/dp.php?dpno=14804

Snouwaert, J. (2020, March 19). The maker of Absolut Vodka and Jameson Irish Whiskey says it is converting its facilities to produce hand sanitizer that it will donate amid the shortage. Business Insider. https://cutt.ly/ QhIGGiD

Swartz, J. (2020, May 2). Amazon will spend \$4 billion or more on coronavirus response, potentially wiping out Q2 profit. Market Watch. https://cutt.ly/PhIGJlb

Williams, J. C. (2020, May 11). The Pandemic Has Exposed the Fallacy of the "Ideal Worker." Harvard Business Review. https://hbr.org/2020/05/the-pandemic-has-exposed-the-fallacy-of-the-ideal-worker

Zhang, R. (2020, March 24). Can "Revenge Spending" Save Luxury in China? Jing Daily. https://jingdaily.com/canrevenge-spending-save-luxury-in-china/

Žižek, S. (2020, February 27). Coronavirus is "Kill Bill”-esque blow to capitalism and could lead to reinvention of communism. Russia Today. https://www.rt.com/op-ed/481831-coronavirus-kill-bill-capitalism-communism/

\section{AUTHOR}

Marco Ambrosi De la Cadena. PhD student of Philosophy at Università Vita-Salute San Raffaele; current research project is Aristotelism and Education in the Real Audiencia de Quito XVI-XVIII. Research interests are Social Epistemology, Gender, Political Philosophy, Social Movements, and History of Ideas. Publications on Social Epistemology, Social Movements and Knowledge Economy.

\section{Conflict of interest}

No potential conflict of interest is reported by the author.

\section{Funding}

No financial assistance from parties outside this article.

\section{Acknowledgment}

$\mathrm{N} / \mathrm{A}$ 